\title{
Potential of Spent Pleurotus ostreatus Mushroom Substrate as Compost
}

\author{
Ramdana Sari ${ }^{1}$, Astuti Arif ${ }^{2}$, Muhammad Restu ${ }^{2}$ dan Retno Prayudyaningsih ${ }^{3}$ \\ ${ }^{1}$ Postgraduate Student, Forestry Faculty, Hasanuddin University, Indonesia \\ ${ }^{2}$ Lecturer, Forestry Faculty, Hasanuddin University, Indonesia \\ ${ }^{3}$ Researcher, Environment and Forestry Research and Development Institute of Makassar, Indonesia
}

\begin{abstract}
Oyster mushroom (Pleurotus ostreatus) cultivation produces waste in the form of mushroom substrate that has passed the production period and contaminated substrate. Non-productive spent mushroom substrates (SMS) still contain nutrients that allow them to be composted. The main goal of this study is to determine the potential of SMS as compost. The composting was done by mixing each of the old substrate waste (P1) and contaminated (P2) with a solution of EM4 and sugar. Temperature measurement and material compost stirring were done every week. The test results after 8 weeks of composting showed that the physical characteristics of compost, including the color and texture, have complied with the standards of SNI 19-70302004, which was brown and smooth. P1 compost has an earthy odor while P2 compost still has a slight woody. The mass of $P 1$ and $P 2$ composts decreased by $32 \%$ and 32,4\%, respectively. Micronutrients such as $F e, Z n$, and Mo were varied and according to SNI 19-7030-2004, Minister of Agriculture Regulations No.28/Permentan/SR.130/5/2009 as well as Minister of Agriculture Regulations No.70/Permentan/SR.140/10/2011. Co did not comply with the standard. The water content, pH, and macronutrients such as $\mathrm{N}$-total, $\mathrm{P}_{2} \mathrm{O}_{5}, \mathrm{~K}_{2} \mathrm{O}$ dan $\mathrm{C}$-organic in both types of compost were according to SNI 197030-2004, Minister of Agriculture Regulations No.28/Permentan/SR.130/5/2009 or Minister of Agriculture Regulations No.70/Permentan/SR.140/10/2011. The C/N ratio in compost was still high, compost P1 and P2 had $25,26 \%$ and $25,16 \%$. To reduce the C/N ratio of compost, it is necessary to carry out several treatments such as increasing the decomposition time or adding other organic materials during the composting process. The addition of organic materials such as manure or bran allows the microbial activators to be optimally in decomposing compost material to shorten the composting time.
\end{abstract}

Keywords - composting, spent mushroom substrate (SMS), compost

\section{INTRODUCTION}

Fertilizer is one of the determining factors for the success of agricultural production or rehabilitation of critical land. The utilization of inorganic fertilizers is still the main choice for most farmers or companies that will carry out rehabilitation. The dosage of inorganic fertilizers is less and easier to decompose so that it can be absorbed and utilized directly by plants [1]. The efficiency of using inorganic fertilizers is considered to give faster results in crop production. However, using inorganic fertilizers for the long term has bad impacts on the environment, such as decreased sucrase activity, soil $\mathrm{pH}$ value, and microbial biomass $\mathrm{C}$, although increasing the soil metabolic quotient (qCO2) [2]. The intensive application of chemical fertilizers in excessive amounts can increase the residue of nitrates and other toxic chemicals in soil [3]. It can contribute to soil and water pollution causing a decrease in soil productivity physically, chemically, and biologically; further, increase greenhouse gas emissions [4]. Technological inputs on a land to produce greater production should pay attention to environmental and natural sustainability [5].

Environmental concerns have caught the attention of organic producers [6] and consumers [7). The application of organic fertilizers is an alternative to increase crop productivity because of its ability to improve soil physical and biological properties, such as increasing soil macropores, about 50-500 $\mu \mathrm{m}$ [8]. In addition, organic fertilizers are also able to provide nutrients quickly to overcome nutrient deficiencies, improving soil structure, storing water, and increasing soil biological activities [9]. Compost is one of the organic fertilizers produced through the composting process of plant and animal remains with the help of living organisms [10]. The stability and quality of compost depend on raw materials, proportions, procedures, and composting time [11]. 
DOI: $\underline{10.51386 / 25815946 / \mathrm{ijsms}-\mathrm{v} 4 \mathrm{i} 5 \mathrm{p} 119}$

Volume: 4 Issue: 5

September to October 2021

https://www.ijsmsjournal.org

Spent oyster mushroom substrate (SMS), either old (past the production period) or contaminated substrate, is a product of mushroom cultivation that can be used as a biofertilizer or soil conditioner [12]. SMS production can reach 2,5 - $5 \mathrm{~kg}$ for every kilogram of mushrooms produced [13] [14]. SMS has great potential considering the national mushroom production data reached 3,32 million $\mathrm{kg}$ in 2020 [15]. The production of spent mushroom compost can contribute to reducing environmental pollution, especially the pungent odor from the decay of SMS and wastewater [16], as well as eliminating the opportunity for plant-destroying pests to breed in SMS [17]. SMS that is not processed properly will have a bad impact on the surrounding environment.

The composition of oyster mushroom substrate commonly used by farmers consists of sawdust, bran, lime, water and can be added decomposer microbes to accelerate substrate maturation [18]. Old or contaminated substrate waste contains macro and micronutrients that are beneficial for plants [19]. Substrate material, which is a mostly organic material, can be processed to be composted so that it has better benefits. This study aims to determine the potential of the spent oyster mushroom substrate, both old and contaminated substrate, as compost material. The utilization of SMS to be used as compost to support plant growth on the lack of nutrients land as well as a solution to overcome waste in nature.

\section{METHODOLOGY}

\section{A. Research Time and Location}

Spent Pleurotus ostreatus mushroom substrate was carried out at the locations for oyster mushroom cultivation in Makassar. Composting was carried out in April - June 2021. Tests of macronutrients (N-total, $\mathrm{P}_{2} \mathrm{O}_{5}, \mathrm{~K}_{2} \mathrm{O}$, and $\mathrm{C}$-organic), $\mathrm{pH}$, water content, and micronutrients (Fe, $\mathrm{Zn}$, and $\mathrm{Co}$ ) were carried out in the soil, plant, fertilizer, water laboratory at the Research Center for Agricultural Technology, South Sulawesi, Maros. Analysis of Mo was carried out at the environmental biotechnology, laboratory of PT Biodiversitas Biotechnology Indonesia, Bogor.

\section{B. Research Procedures}

\section{1) Material Preparation}

SMS that will be used as the basic material for compost is separated first between the old and contaminated substrate. SMS is crushed and sifted. The substrate destruction process is carried out to get smaller material particles. Compost materials with small sizes make it easier for microorganisms to decompose the inside of substrate material particles [20]. The purpose of sifting is to separate solid SMS materials, such as clumping media, corn kernels which are carriers of oyster mushroom seeds, wood, or other impurities. SMS that has been cleaned and then weighed as much as $10 \mathrm{~kg}$ (each for old and contaminated SMS). In addition, other ingredients prepared are $20 \mathrm{ml}$ of EM4 and 10 grams of granulated sugar which has been dissolved in water.

\section{2) Composting}

The composting of SMS was divided into 2 types of treatment, namely compost with basic materials from an old substrate (P1) and contaminated substrate (P2). SMS that has been sifted was added with EM4 and molasses [21]. The compost materials were stirred until evenly distributed. When the compost material was still dry, water was added until the water content is about 50-60\% [22]. The appropriate water content is indicated by the water does not drip when the compost material is clenched and does not scatter when the fist is removed. The low water content in the compost material can cause the decomposer microbial activities to stop so that the decomposition process of the organic matter becomes imperfect [17]. On the other hand, a water content that is too high causes water to fill the space between particles of organic matter, thereby inhibiting the movement of air in the pile [23]. After the materials are evenly mixed, put into a bucket and tightly closed for the composting process.

\section{3) Stirring}

Mixing was done every week for 8 weeks by stirring the composted material in a bucket. Stirring aims so that the raw materials can be mixed evenly, decomposition process can be faster.

\section{4) Observation}

Measurements were made on the temperature formed during the composting process, physical compost, micro and macronutrients, water content, and $\mathrm{pH}$. Temperature measurements were carried out every week before stirring, for 8 weeks. Physical observations of compost including color, odor, mass, and texture 


\section{DOI: $10.51386 / 25815946 / \mathrm{ijsms}-\mathrm{v} 4 \mathrm{i} 5 \mathrm{p} 119$}

Volume: 4 Issue: 5

September to October 2021

https://www.ijsmsjournal.org

were carried out after 8 weeks of the composting process. Similarly, the analysis of macronutrients (N-total, $\mathrm{P}_{2} \mathrm{O}_{5}, \mathrm{~K}_{2} \mathrm{O}$, and C-organic) and micronutrients ( $\mathrm{Fe}, \mathrm{Zn}, \mathrm{Co}$, and $\mathrm{Mo}$ ), $\mathrm{pH}$, and water content.

\section{Data Analysis}

The qualitative and quantitative data obtained were compared with the compost criteria according to SNI 19-7030-2004, Minister of Agriculture Regulations No.28/permentan/SR.130/5/2009 and Minister of Agriculture Regulations No.70/Permentan/SR.140/10/2011. Descriptive analysis is used to identify, describe and quantify the research results that have been obtained as they are [24].

\section{RESULTS AND DISCUSSION}

\section{A. Results}

SMS changes during the composting process. Changes that occur include color, odor, mass, and compost temperature. Nutrient content measurements were carried out at the end of composting.

\section{1) Compost color}

The old substrate waste before composting is light brown while the contaminated substrate waste is brown. Oyster mushroom mycelium is seen in the old substrate, but it is no longer productive. After 8 weeks of composting, compost with the basic ingredients of old substrate waste (P1) turns brown. Compost also contains more water than before composting. Compost that still contains water must be dried for 1-2 days before use [25].
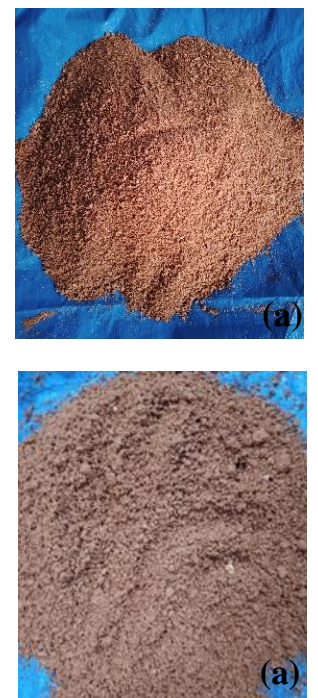
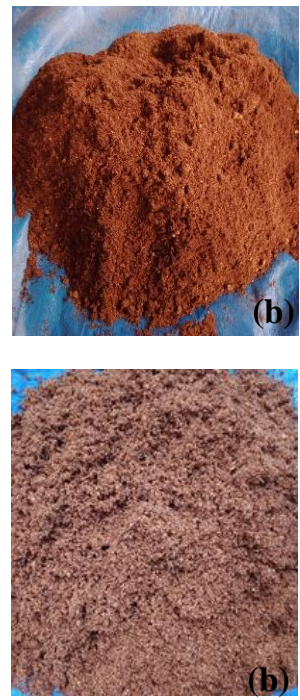

Figure 1. (A) compost material before composting: (a) old substrate waste, (b) contaminated substrate waste; (B) compost after composting: (a) old substrate waste compost (P1), (b) contaminated substrate waste compost (P2) (doc. Ramdana Sari)

Color changes also occur in compost made from contaminated substrate waste (P2). The compost is dark brown at the end of composting (Figure 1).

\section{2) Compost odor and mass}

SMS has a distinctive odor. The old substrate waste smells like stale food, while contaminated substrate waste has a wood smell. In the early stages of composting, SMS that has been mixed with bio activator emits a pungent odor which indicates that the decomposer microbes were composting actively.

The compost mass has decreased from the initial mass. The amount of mass shrinkage of P1 and P2 compost was $32 \%$ and $32.4 \%$ at the end of the composting.

\section{3) Temperature change during composting}

The composting temperature for 8 weeks of observations ranged from $26^{\circ}-31^{\circ} \mathrm{C}$ (figure 2). The highest temperature was reached in the $4^{\text {th }}$ week of observations, it was $30^{\circ} \mathrm{C}$ for $\mathrm{P} 1$ compost and $31^{\circ} \mathrm{C}$ for $\mathrm{P} 2$ compost. The temperature of the compost was stable at $27^{\circ} \mathrm{C}$ at the end of composting. Based on SNI-19-7030-2004, a good compost temperature ranges from $26^{\circ}-30^{\circ} \mathrm{C}$ (groundwater temperature). 
DOI: $\underline{10.51386 / 25815946 / \mathrm{ijsms}-\mathrm{v} 4 \mathrm{i} 5 \mathrm{p} 119}$

Volume: 4 Issue: 5

September to October 2021

https://www.ijssmsjournal.org

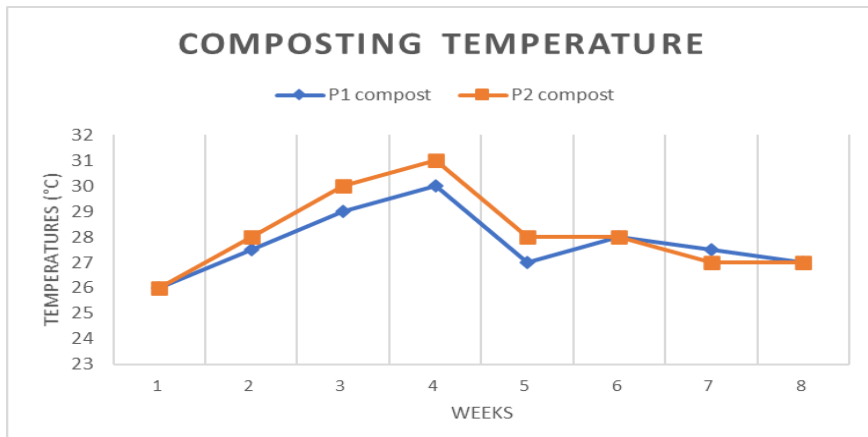

Figure 2. changes in temperature formed during composting

\section{4) Nutrient Content and Physical Properties of Compost}

Tests for nutrient content, water content, and $\mathrm{pH}$ of compost made from SMS were carried out after 8 weeks of composting. Differences in macro, micro, $\mathrm{pH}$, and water content between $\mathrm{P} 1$ and $\mathrm{P} 2$ compost can be seen in table 2. Generally, the nutrient content in P1 compost is higher than P2 compost. The old substrate waste has undergone a process of decomposition of organic matter during the growth process of oyster mushrooms. Therefore, old substrate waste which was used as the basis for compost requires a relatively short time to reach perfect maturity compared to contaminated substrate waste. Compost that still takes time for the composting process contains lower nutrients because it is absorbed and used by microbes to live and decompose material substrate [26].

Table 1. Nutrient Content and Physical Properties of Compost

\begin{tabular}{|c|c|c|c|c|c|c|c|c|c|}
\hline \multirow[t]{2}{*}{ No } & \multirow[t]{2}{*}{ Parameter } & \multirow[t]{2}{*}{$\begin{array}{c}\text { Old } \\
\text { Substrate } \\
\text { Waste } \\
\text { Compost }\end{array}$} & \multirow[t]{2}{*}{$\begin{array}{c}\text { Contaminated } \\
\text { Substrate } \\
\text { Waste Compost }\end{array}$} & \multicolumn{2}{|c|}{ SNI 19-7030-2004 } & \multicolumn{2}{|c|}{$\begin{array}{c}\text { Minister of } \\
\text { Agricultural } \\
\text { Regulations } \\
\text { No.28/Permentan/S } \\
\text { R.130/5/2009 }\end{array}$} & \multicolumn{2}{|c|}{$\begin{array}{c}\text { Minister of } \\
\text { Agricultural } \\
\text { Regulations } \\
\text { No.70/Permentan/S } \\
\text { R.140/10/2011 }\end{array}$} \\
\hline & & & & Min. & Maks. & Min. & Maks. & Min. & Maks. \\
\hline 1 & N-total, $\%$ & 0.95 & 1.55 & 0.40 & - & - & 6 & - & - \\
\hline 2 & $\mathrm{P}_{2} \mathrm{O}_{5}, \%$ & 0.18 & 0.07 & 0.10 & - & - & 6 & - & - \\
\hline 3 & $\mathrm{~K}_{2} \mathrm{O}, \%$ & 0.84 & 0.71 & 0.20 & - & - & 6 & - & - \\
\hline 4 & C-Organic, $\%$ & 24 & 39 & 9.80 & 32 & 12 & - & 15 & - \\
\hline 5 & $\mathrm{C} / \mathrm{N}$ ratio, $\%$ & 25.26 & 25.16 & 10 & 20 & 15 & 25 & 15 & 25 \\
\hline 6 & $\mathrm{pH}$ & 8.98 & 8.77 & 6.80 & 7.49 & 4 & 8 & 4 & 9 \\
\hline 7 & Water content, \% & 38 & 20 & - & 50 & 15 & 25 & 15 & 25 \\
\hline 8 & $\mathrm{Fe}, \mathrm{ppm}$ & 621 & 209 & - & - & - & 8000 & - & 9000 \\
\hline 9 & $\mathrm{Zn}, \mathrm{ppm}$ & 420 & 280 & - & 500 & - & 5000 & - & 5000 \\
\hline 10 & Co, ppm & 353 & 168 & - & 34 & - & 20 & - & - \\
\hline 11 & Mo, ppm & 1.22 & 1.04 & - & - & - & 10 & - & - \\
\hline
\end{tabular}

\section{B. Discussions}

Composting is a decomposition of organic matter with the help of microbes [4]. The result of the decomposition process is compost which can be used to improve soil and fertilize plants. One of the organic materials that can be used as the basic materials for compost is the non-productive spent mushroom substrate (SMS). Generally, the productive period of oyster mushroom substrate ranges from 3-4 months. After that, the growth of mushrooms on the substrate will decrease. Farmers usually will replace the new substrate in the mushroom house. Substrate waste, both old and contaminated substrate, will be separated and disposed of. SMS 
DOI: $\underline{10.51386 / 25815946 / \mathrm{ijsms}-\mathrm{v} 4 \mathrm{i} 5 \mathrm{p} 119}$

Volume: 4 Issue: 5

September to October 2021

https://www.ijsmsjournal.org

will become a waste if it is allowed without a good management process. Even though SMS still has the potential to be used as compost material.

Spent mushroom substrate (SMS), such as spent oyster substrate, still contains sufficient nutrients to be processed into compost [19]. The old substrate has lower nutritional content than the contaminated substrate. This is because oysters that are heterotrophs utilize the nutrients contained in a substrate to support their growth. Although most of the nutrients in old substrate have been utilized by the oysters, the remaining nutrients can still be processed into compost [16].

SMS can undergo a natural decomposition process, but it takes quite a long time. Composting will run faster if microorganisms are added as bio activators. The bio activators are microorganisms that play a role in activating and initiating changes in the physical and chemical properties of organic materials to produce products that are different from the previous properties [23]. Bioactivator agents that play a role in the decomposition process of cellulose during composting consist of types of bacteria and fungi [27]. EM4 is one of the bio activator products that can accelerate the decomposition process, increase soil nutrients, and improve soil structure [23].

\section{1) Compost Color}

An indicator of the success of the composting process is the occurrence of color changes in the compost material. Compost that is suitable for use as an organic fertilizer has a slightly dark color (blackish brown) resembling soil [16]. The color change is caused by microbial activities that remodel the compost material so that the overhauled compost material changes color [20].

\section{2) Compost Odor and Mass}

A pungent odor will be produced during the fermentation process, depending on the microbial activities and the compost material used [28]. After 8 weeks of observation, the smell of P1 compost changed to the smell of earth. This is an indicator that the compost was ripe and ready for use. While the P2 compost still had a slight woody odor. This indicates that $\mathrm{P} 2$ compost still requires a longer composting time.

Compost will decrease in mass to about 50\% of its original mass [29]. The decomposition of organic matter by microbes causes the water content to decrease [30]. In addition, the evaporation due to the heat energy generated during the composting process also causes the volume of the compost material to shrink. Characteristics of compost material and the maturity level of the compost are the determining factors for the amount of shrinkage that occurs [30].

\section{3) Temperature Change During Composting}

Microbes that can live at a temperature of $20-35^{\circ} \mathrm{C}$ belong to the mesophilic group of microbes [23]. Optimal temperature and environmental conditions for microbial decomposers will support the composting. Microbes will utilize $\mathrm{O}_{2}$ from the compost pile and release $\mathrm{CO}_{2}$ and heat energy during the composting [27]. Microbes will utilize compost organic matter as nutrients to support their metabolic activities. Decomposer microbes will also multiply by releasing a certain amount of energy in the form of heat, thereby increasing the temperature in the compost pile [27]. After passing the maximum temperature, the decomposition process will slowly stabilize because most of the organic matter has been decomposed and the high oxygen demand has been [23].

\section{4) Nutrient Contents and Physical Properties of Compost}

a) Macronutrients Content

Macronutrients consist of Carbon (C), Nitrogen (N), Phosphorus (P), and Potassium (K). The presence of these elements is very important to support plant growth. Macronutrients are needed by plants in large amounts. The concentration of macronutrients in the dry weight of plant tissue was $\geq 0.1 \%$ (1000 ppm) [30]. One of the essential nutrients that plants need in large amounts is carbon. The C-organic element is a constituent of bacterial cell walls [32] as well as a source of energy for microbial decomposers in the composting process 33].

C-organic analysis of the compost was carried out using the ashing method. The carbon content in P1 compost (C-organic 24\%) complied with quality compost standards based on SNI-19-7030-2004 and Minister of Agriculture Regulations No.70/Permentan/SR.140/10/2011. P2 compost had a carbon content (C-organic 39\%) exceeding the maximum standard of SNI [34] but still complied the criteria of Minister of Agriculture Regulations No.70/Permentan/SR.140/10/2011 (Table 1). Organic materials derived from wood, leaves, and 
DOI: $\underline{10.51386 / 25815946 / \mathrm{ijsms}-\mathrm{v} 4 \mathrm{i} 5 \mathrm{p} 119}$

Volume: 4 Issue: 5

September to October 2021

https://www.ijsmsjournal.org

twigs become a carbon source in the composting process [32]. Wood dust and bran which are the main ingredients of oyster mushroom substrate cause high carbon content in the substrate [19]. An oyster which is a heterotrophic organism utilizes and decomposes substrate carbon sources for its metabolic needs. Therefore, the carbon content in the old substrate will decrease after passing the production period. The contaminated substrate also has a high carbon content. The contaminated substrate that has not been overgrown with oyster mushrooms still has a high carbon content. This affects the $\mathrm{C}$-organic content after composting.

Nitrogen plays a role in the formation of enzymes and amino acids [33]. In the composting process, nitrogen is also utilized by decomposer microbes to support their activities. Therefore, the availability of high amounts of nitrogen in the compost material will accelerate the decomposition of organic matter [17]. Determination of nitrogen content in compost was carried out using the Kjeldahl method. The nitrogen content in P1 compost was $0.95 \%$ and $\mathrm{P} 2$ compost was $1.55 \%$ (Table 1). The N-total compost had complied with the quality compost requirements based on SNI 19-7030-2004 because it was above 0.40\% [34]. In addition, the Ntotal compost was also below the maximum limit based on the Minister of Agriculture Regulations No.28/Permentan/SR.130/5/2009, which is 6\% [35]. The source of nitrogen in the spent oyster mushroom substrate compost comes from the addition of bran when making substrate [19].

The ripe compost with good quality can be seen in the C/N ratio. Based on SNI 19-7030-2004 and Minister of Agriculture Regulations No.28/Permentan/SR.130/5/2009, a good C/N ratio range from $10-20 \%$ and $15-25 \%$. The $\mathrm{C} / \mathrm{N}$ ratio depends on the $\mathrm{C}$-organic and $\mathrm{N}$-total content in the compost. The composting process aims to reduce the $\mathrm{C} / \mathrm{N}$ ratio in organic matter to the same or close to the soil $\mathrm{C} / \mathrm{N}$ ratio $(<20)[36]$. The higher $\mathrm{C}$-organic content compared to $\mathrm{N}$-total causes the $\mathrm{C} / \mathrm{N}$ ratio to be high, while the lower $\mathrm{C}$-organic content compared to $\mathrm{N}$-total causes the $\mathrm{C} / \mathrm{N}$ ratio to also be low. The $\mathrm{C} / \mathrm{N}$ ratio that is too high can cause the activity of microbial decomposers to be inhibited due to a lack of nitrogen, while a $\mathrm{C} / \mathrm{N}$ ratio that is too low causes nitrogen to evaporate easily due to the formation of ammonia gas in the compost [36]. P1 and P2 compost still had high $\mathrm{C} / \mathrm{N}$ ratios (25.26\% and $25.16 \%$, respectively). Thus, the $\mathrm{C} / \mathrm{N}$ ratio of compost from SMS produced from the composting process for 8 weeks did not comply with the standards based on SNI and the Minister of Agriculture Regulations (Table 1). However, the $\mathrm{C} / \mathrm{N}$ ratio of 20 - 40 is still efficient for the decomposition process [33].

Phosphorus is a nutrient that plants need in large amounts. The role of phosphorus is no less important than carbon and nitrogen. Phosphorus is an important element in the formation of proteins for macroorganisms and microorganisms [17]. The presence of P-total in the soil is less than nitrogen, potassium, and calcium [19]. To comply with the needs of plant phosphorus, it is necessary to introduce it with the addition of fertilizer. Testing of phosphorus content in compost was carried out by spectrophotometric method. Based on SNI 197030-2004, good quality compost has a total P content $\geq 0.10 \%$. P1 Compost which has a P-total of $0.18 \%$ has complied with the standard of SNI 19-7030-2004, while P2 compost with a P-total of $0.07 \%$ did not comply with the minimum standard of SNI 19-7030-2004 but is still following under the Minister of Agriculture Regulations No.28/Permentan/ SR.130/5/2009 is $\leq 6$ (Table 1).

Potassium in compost comes from fresh organic matter in the form of complex compounds that cannot be utilized directly by plants [37]. The composting process by microbes decomposes complex compounds into simple compounds and produces $\mathrm{K}^{+}$ions which can be absorbed by plants [38]. Free $\mathrm{K}^{+}$ions are also utilized by bacteria for their metabolism [17]. In addition, $\mathrm{K}^{+}$ions act as activators of several enzymes in plant metabolic processes [19]. The minimum standard of potassium content in quality compost based on SNI 19-7030-2004 is $0.20 \%$ [34]. P1 Compost had a K-total of $0.84 \%$ while P2 compost had $0.71 \%$ so that it complied with the standards of SNI 19-7030-2004 (Table 1).

\section{b) Micronutrients Content}

Micronutrients are nutrients needed by plants in small amounts, $\leq 0.01 \%$ (100 ppm) in the dry weight of plant tissue [31]. Although it is needed in relatively small amounts, it plays an important role in plant metabolism, especially to help enzymes work [39]. The deficiency of micronutrients can interfere with enzyme performance, on the contrary, excess of micronutrients can cause poisoning in plants [31]. In addition, some micronutrients are also used by symbiotic microorganisms to infect plant roots. Micronutrients that are important for plants and soil microorganisms include iron (Fe), manganese (Mn), molybdenum (Mo) [9], and cobalt (Co) [40]. 
DOI: $\underline{10.51386 / 25815946 / \mathrm{ijsms}-\mathrm{v} 4 \mathrm{i} 5 \mathrm{p} 119}$

Volume: 4 Issue: 5

September to October 2021

https://www.ijsmsjournal.org

Iron $(\mathrm{Fe})$ as an essential nutrient is a constituent of chlorophylls, proteins, enzymes and plays a role in the development of chloroplasts. Fe deficiency causes inhibition of chlorophyll formation so that leaves turn yellow and protein synthesis is not perfect [41]. For groups of Rhizobia bacteria that have a symbiosis with legumes, $\mathrm{Fe}$ is needed to compile the nitrogenase enzyme which plays a role in the nitrogen-fixing process [42]. Analysis of Fe content in compost was carried out using the Atomic Absorption Spectrophotometry (AAS) method. The total Fe content in P1 compost was $621 \mathrm{ppm}$, which was higher than P2 compost at 209 ppm. However, the total Fe content in both types of compost still complied with the quality compost standard based on the Minister of Agriculture Regulations No.70/Permentan/SR.140/10/2011, which was $\leq 9000$ ppm [43]. Total Fe is the Fe content in compost, including available and unavailable Fe [44].

Zinc $(\mathrm{Zn})$ content in compost was analyzed by Atomic Absorption Spectrophotometry (AAS) method. The total $\mathrm{Zn}$ content of $\mathrm{P} 1$ compost is $420 \mathrm{ppm}$, higher than P2 compost which only contains 280 ppm. Both types of compost have $\mathrm{Zn}$ content according to the minimum technical requirement of solid organic fertilizer of Minister of Agriculture Regulations No.70/Permentan/SR.140/10/2011, which is $\leq 5000$ ppm [43]. Zn is one of the essential micronutrients which is a co-factor for more than 300 types of enzymes that play a role in protein synthesis, cell division, and nucleic acid metabolism in plants [45]. $\mathrm{Zn}$ minerals can also function as a catalyst to synthesize bacterial digestive enzymes, such as cellulosic enzymes [46].

Cobalt (Co) is also a micronutrient that has an important role for plants. Legume plants require more Co than non-legume plants because the presence of this element greatly affects the rhizobia bacteria that colonize their roots [47]. The element Co acts as a component of leghaemoglobin which contributes to the efficiency of nitrogen fixation of rhizobia bacteria in legume root nodules [42]. The Atomic Absorption Spectrophotometry (AAS) test method was carried out to determine the Co content in the compost. The Co content of $353 \mathrm{ppm}$ in P1 compost was higher than P2 compost at $168 \mathrm{ppm}$. Co content in substrate waste compost did not comply with quality compost standards based on SNI 19-7030-2004 which must be below 34 ppm and Minister of Agriculture Regulations No.28/Permentan/SR.130/5/2009 with a maximum Co of 20 ppm. Heavy metals in compost can be toxic to plants if they are above a critical threshold. The critical threshold for metal Co in plants ranges from 30 - 40 ppm [48].

Molybdenum (Mo) content in compost was analyzed by Atomic Absorption Spectrophotometry (AAS) method. P1 compost contains $1.22 \mathrm{ppm}$ and P2 compost with $1.04 \mathrm{ppm}$. Mo with Fe form Fe-Mo protein which is the center of activity for nitrogen fixation bacteria to reduce nitrogen in the air [42]. Giving Mo can cause legume root nodules to get bigger and more physiologically active. The pithy root nodules with active bacteroids in them cause the $\mathrm{N}$ fixation to be higher. According to the Minister of Agriculture Regulations No.28/Permentan/SR.130/5/2009, the Mo content in compost still complied with the standard because it was $\leq$ $10 \mathrm{ppm}[35]$.

\section{c) Water Content of Compos}

Water content is the percentage of water contained in a material based on wet weight (wet basis) or dry weight (dry basis) [38]. Water content is an important factor affecting the composting process. The optimal water content helps decomposer microbes to decompose organic material in compost material [17]. Decomposition of organic matter in the early stages of composting produces a liquid called leachate so that it affects the moisture of the compost material. The stirring process carried out every week can create good aeration in the compost material so that the oxygen supply for microbes can be controlled. Analysis of water content in compost through the oven method. The water content of both types of compost still complied with the optimal quality compost standard based on SNI 19-7030-2004, which is $\leq 50 \%$ [34]. P1 and P2 composts have a water content of $38 \%$ and $20 \%$.

\section{d) Degree of Acidity (pH) Compost}

The degree of acidity is one of the physical parameters that must be considered in the composting process. Measurement of $\mathrm{pH}$ at the end of the composting using the electrometric method showed a fairly high $\mathrm{pH}$ value for both $\mathrm{P} 1$ and $\mathrm{P} 2$ compost, they were 8.98 and 8.77. Although it did not comply with the quality compost requirements according to SNI 19-7030-2004, it is still classified as good compost based on Minister of Agriculture Regulations No. 70/Permentan/SR.140/10/2011, which was in the pH range of $4-9$ [43]. The 


\section{DOI: $\underline{10.51386 / 25815946 / \mathrm{ijsms}-\mathrm{v} 4 \mathrm{i} 5 \mathrm{p} 119}$}

Volume: 4 Issue: 5

September to October 2021

https://www.ijsmsjournal.org

advantage of compost that has a high $\mathrm{pH}$ is that it can be applied to acidic soils [17]. The high $\mathrm{pH}$ of compost can increase the acid $\mathrm{pH}$ of agricultural soil or land that is the target of reclamation.

\section{IV.CONCLUSIONS}

A. Conclusions

1) The compost of old substrate waste (P1) and contaminated substrate waste (P2) have color, mass, temperature, macronutrients content ( $\mathrm{N}$-total, $\mathrm{P}_{2} \mathrm{O}_{5}, \mathrm{~K}_{2} \mathrm{O}$, and $\mathrm{C}$-organic), micronutrients content (Fe, $\mathrm{Zn}$, and $\mathrm{Mo}$ ), $\mathrm{pH}$, and water content that have complied quality compost standards based on SNI 19-7030-2004, Minister of Agriculture Regulations No.28/Permentan/SR.130/5/2009 and Minister of Agriculture Regulations No.70/Permentan/SR.140/10/2011.

2) The old substrate waste compost (P1) generally contains higher macro and micronutrients than the contaminated substrate waste compost (P2).

3) Nutrient content of $\mathrm{Co}$ and $\mathrm{C} / \mathrm{N}$ ratio in $\mathrm{P} 1$ and $\mathrm{P} 2$ composts did not comply with the criteria for quality compost, as did the odor in $\mathrm{P} 2$ compost.

\section{B. Suggestion}

To reduce the $\mathrm{C} / \mathrm{N}$ ratio of compost, it is necessary to carry out several treatments such as increasing the composting time or adding other organic materials. The addition of organic materials such as manure or bran allows microbial activators can work optimally in decomposing compost material so that it can shorten the composting time.

\section{ACKNOWLEDGMENT}

We would like to thank the oyster mushroom cultivation house 'Rumah Pink Jamur' for allowing us to collect the spent oyster mushroom substrate. We also express our gratitude to Andi Sri Rahmah Dania, a laboratory assistant from the microbiology laboratory, Environmental and Forestry Research and Development Institute of Makassar, who has assisted in the composting process.

\section{REFERENCES}

[1] Purnomo, R., Santoso, M., \& Heddy, S. (2013). Pengaruh berbagai macam pupuk organik dan anorganik terhadap pertumbuhan dan hasil tanaman mentimun (Cucumis sativus L.). Jurnal Produksi Tanaman, 1(3), 93-100

[2] Ge, G., Fan, F., Chu, G., Hou, Z. amd Liang, Y. 2010. Soil biological activity and their seasonal variations in response to long-term application of organic and inorganic. Plant and Soil, 326, doi.org/10/1007/s11104-009-0186-8.

[3] Weinbaum, S. A., Johnson, R. S. dan DeJong, T. M. 1992. Causes and consequences of overfertilization in orchards. Hort Technology, 2, 112-132.

[4] Walsh, J. J., Jones, D. L., Edwards-Jones, G. and Williams, A. P. 2012. Replacing inorganic fertilizer with anaerobic digestate may maintain agricultural productivity at less environmental cost. Journal of Plant Nutrition and Soil Science, 175, 840-845.

[5] Villaver, J. P. and Agan, E. 2019. Agronomic response of sweet corn (Zea mays L. var. rogusa) to fermented agar-agar (Eucheuma cottonii) and methods of application. International Journal of Science and Management Studies (IJSMS), 1 (5), $67-73$.

[6] Travernier, E. M. 2004. An empirical analysis of producer perceptions of traceability in organic agriculture. Renewable Agriculture and Food Systems, 19 (2), 110-117.

[7] Hughner, R. S., McDonagh, P., Prothero, A., Shultz CJ, Stanton, J. 2007. Who are organic food consumers? A compilation and review of why people purchase organic food. Journal of Consumer Behavior, 6, 94-110.

[8] Marinari, S., Masciandro, G., Ceccanti, B. and Grego, S. 2000. Influence of organic and mineral fertilizers on soil biological and physical properties. Bioresource Technology, 72 (1), 9-17.

[9] Palupi, N. P. (2015). Karakter kimia kompos dengan dekomposer mikroorganisme lokal asal limbah sayuran. Ziraa'Ah, 40(1), 54-60.

[10] Pergola, M., Persiani, A., Palese, A. M., Meo, V. D., Pastore, V., D’Adamo, G. and Celano, G. Composting: The way for a sustainable agriculture. Applied Soil Ecology, 123, 744-750.

[11] Muscolo, A., Papalia, T., Settineri, G., Mallamaci, C. and Karczanowska, A. J. 2018. Are raw materials or composting conditions and time that most influence the maturity and/or quality of composts? Comparison of obtained compost on soil properties. Journal of Cleaner Production, 195, 93-101.

[12] Priadi, D. and Saskiawan, I. 2018. The utilization of spent mushroom substrates into compost and its effect on the growth of indian mustard (Brassica juncea (L.) Czem.) in screenhouse. International Journal of Agricultural Technology, 14 (3), $351-362$.

[13] Medina, E., Paredes, C., Bustamante, M. A., Moral, R. and Moreno-Caselles, J. 2012. Relationships between soil physico-chemical, chemical, and biological properties in a soil amended with spent mushroom substrate. Geoderma, 173, $152-161$. 


\section{DOI: $\underline{10.51386 / 25815946 / i j s m s-v 4 i 5 p 119}$}

Volume: 4 Issue: 5
September to October 2021

\section{https://www.ijsmsjournal.org}

[14] Priadi, D. Arfiani, A., Saskiawan, I. and Mulyaningsih, E. S. 2016. Use of grass and spent mushroom compost as a growing medium of local tomato (Lycopersicon esculentum Miller) seedling in the nursery. AGRIVITA, Journal of Agricultural Science, 38 (3), $242-$ 250 .

[15] BPS-Statistic Indonesia. 2020. Produksi Tanaman Sayuran. 2020. http://www.bps.co.id [accessed on 11 oktober 2021].

[16] Adinurani, P. G., \& Rahayu, S. (2021). Penanganan limbah baglog jamur tiram (Pleurotus osteatus) di Desa Bodag Kecamatan Kare Kabupaten Madiun. Dinamisia: Jurnal Pengabdian Kepada Masyarakat, 5(1), $206-213$. https://doi.org/10.31849/dinamisia.v5i1.4523

[17] Jumar, Saputra, R. A., \& Putri, K. A. (2021). Kualitas kompos limbah baglog jamur tiram. Prosiding Seminar Nasional Lingkungan Lahan Basah, 6(1).

[18] Sari, E., \& Ropalia. (2019). Peningkatan keterampilan masyarakat melalui pelatihan pembibitan dan pembuatan baglog jamur tiram putih di Desa Pagarawan, Bangka. Intelektiva: Jurnal Ekonomi, Sosial \& Humaniora, 01(04), 1-7.

[19] Kusuma, W. (2014). Kandungan nitrogen (N), fosfor (P) dan kalium (K) limbah baglog jamur tiram (Pleurotus ostreatus) dan jamur kuping (Auricularia auricula) guna pemanfaatannya sebagai pupuk. Fakultas Peternakan. Universitas Hasanuddin. Makassar.

[20] Kusmiadi, R., Khodijah, N. S., \& Royalaitani. (2015). Penambahan gedebong pisang pada kompos bulu ayam dengan berbagai jenis aktivator. Jurnal Pertanian dan Lingkungan, 8(1), 19-30.

[21] Hunaepi, H., Dharawibawa, I. D., Samsuri, T., Mirawati, B., \& Asy'ari, M. (2018). Pengolahan limbah baglog jamur tiram menjadi pupuk organik komersil. Jurnal SOLMA, 7(2), 277-288. https://doi.org/10.29405/solma.v7i2.1392

[22] Sahwan, F. L. (2010). Kualitas produk kompos dan karakteristik proses pengomposan sampah kota tanpa pemilahan awal. Jurnal Teknik Lingkungan, 11(1), 79-85.

[23] Andriany, Fahruddin, \& Abdullah, A. (2018). Pengaruh jenis bioaktivator terhadap laju dekomposisi seresah daun jati Tectona grandis L.f., di wilayah kampus UNHAS Tamalanrea. Bioma : Jurnal Biologi Makassar, 3(2), 31-42.

[24] Gilette, M. 1984. Applications of descriptive analysis. Journal of Food Protection, 47 (5), 403-409.

[25] Indriyanti, D. R., Banowati, E., \& Margunani. (2015). Pengolahan limbah organik sampah pasar menjadi kompos. Jurnal Abdimas, 19(1), 43-48.

[26] Setyorini, D., Saraswati, R., \& Anwar, E. K. (2006). Kompos. In Pupuk Organik dan Pupuk Hayati (pp. 11-40).

[27] Widawati, S. (2005). Daya pacu aktivator fungi asal kebun biologi Wamena terhadap kematangan hara kompos, serta jumlah mikroba pelarut fosfat dan penambat nitrogen. Biodiversitas, 6(4), 238-241. https://doi.org/10.13057/biodiv/d060404

[28] Hamzah, A., Yunandra, \& Pebriandi. (2020). Pemanfaatan limbah masyarakat dalam pembuatan pupuk kompos di Desa Kuok. JCSPA: Journal of Community Services Public Affairs, 1(1), 7-10.

[29] Setyaningsih, E., Astuti, D. S., \& Astuti, R. (2017). Kompos daun solusi kreatif pengendali limbah. Bioeksperimen: Jurnal Penelitian Biologi, 3(2), 45-51. https://doi.org/10.23917/bioeksperimen.v3i2.5181

[30] Winata, R. C. A. (2011). Studi pengomposan eceng gondok (Eichornia crassipes) dan jerami padi dengan penambahan biodekomposer. Jurusan Biologi. Fakultas Sains Dan Teknologi. Universitas Islam Negeri (UIN) Maulana Malik Ibrahim. Malang.

[31] Seran, R. (2017). Pengaruh mangan sebagai unsur hara mikro esensial terhadap kesuburan tanah dan tanaman. Jurnal Pendidikan Biologi, 2(1), 13-14. http://jurnal.unimor.ac.id/JBE/article/view/518

[32] Mufti, A. A., Harliyanti, P., \& Lisafitri, Y. (2021). Uji efektivitas cacing tanah, kotoran sapi dan EM4 terhadap pengomposan serbuk gergaji kayu jati. Jurnal SEOI - Fakultas Teknik Universitas Sahid Jakarta, 3(1), 1-11.

[33] Suhastyo, A. A. (2017). Pemberdayaan masyarakat melalui pelatihan pembuatan pupuk kompos. Jurnal Pengabdian Dan Pemberdayaan Masyarakat, 1(2), 63-68. http://jurnalnasional.ump.ac.id/index.php/JPPM/article/view/1425/1633\%0A

[34] Badan Standar Nasional, Standar Nasional Indonesia tentang Spesifikasi Kompos dari Sampah Organik Domestik (2004).

[35] Kementerian Pertanian, (2009). Peraturan Menteri Pertanian Nomor 28/Permentan/SR.130/5/2009 tentang Pupuk Organik, Pupuk Hayati dan Pembenah Tanah.

[36] Budiarta, I. W., Sumiyati, \& Setiyo, Y. (2017). Pengaruh saluran aerasi pada pengomposan berbahan baku jerami. BETA (Biosistem Dan Teknik Pertanian), 5(1), 68-75.

[37] Bachtiar, B., \& Ahmad, A. H. (2019). Analisis kandungan hara kompos Johar Cassia siamea dengan Penambahan aktivator promi. Jurnal Biologi Makassar, 4(1), 68-76.

[38] Widarti, B. N., Wardhini, W. K., \& Sarwono, E. (2015). Pengaruh rasio C/N bahan baku pada pembuatan kompos dari kubis dan kulit pisang. Jurnal Integrasi Proses, 5(2), 75-80.

[39] Andini, I. M., Roviq, M., \& Nihayati, E. (2015). Pertumbuhan dan kadar kurkumin temulawak (Curcuma xanthorrhiza Robx.) pada ketersediaan unsur hara mikro (Mo) secara in vitro. Jurnal Produksi Tanaman, 3(7), 542-546.

[40] Farooq, Wahid, A. and Siddique, K. H. M. 2012. Micronutrient application through seed treatments - a review. Journal of Soil Science and Plant Nutritions, 12 (1), 125-142. 


\section{DOI: $\underline{10.51386 / 25815946 / \mathrm{ijsms}-\mathrm{v} 4 \mathrm{i} 5 \mathrm{p} 119}$}

Volume: 4 Issue: 5

[41] Jovita, D. (2018). Analisis unsur makro (K, Ca, Mg) mikro (Fe, $\mathrm{Zn}, \mathrm{Cu}$ ) pada lahan pertanian dengan metode Inductively Coupled Plasma Optical Emission Spectrofotometry (ICP-OES). In Skripsi. Fakultas Matematika dan Ilmu Pengetahuan Alam. Universitas Lampung. Bandar Lampung.

[42] Maharani, P. H., Barus, P. A., \& Ningsih, R. D. (2020). Peranan unsur besi (Fe), molibdenum (Mo), dan cobalt (Co) serta upaya meningkatkan ketersediannya dalam menunjang aktivitas bintil akar pada tanaman leguminose. Jurnal Informasi Teknologi Pertanian (JITP), 1(1), 54-71.

[43] Kementerian Pertanian, (2011). Peraturan Menteri Pertanian Nomor 70/Permentan/SR.140/10/2011 tentang Pupuk Organik, Pupuk Hayati dan Pembenah Tanah. http://www.elsevier.com/locate/scp

[44] Kusumawati, A. (2015). Analisa karakteristik pupuk kompos berbahan batang pisang. Seminar Nasional Universitas PGRI Yogyakarta, 323-329.

[45] Fauziah, F., Wulansari, R., \& Rezamela, E. (2018). Pengaruh pemberian pupuk mikro Zn dan Cu serta pupuk tanah terhadap perkembangan Empoasca sp. pada areal tanaman teh. Jurnal Agrikultura, 29(1), 26-34. https://doi.org/10.24198/agrikultura.v29i1.16923

[46] Sunaryati, Muktiani, A., \& Achmadi, J. (2013). Suplementasi temulawak (Curcuma xanthoriza) dan Zn proteinat terhadap konsumsi dan produksi energi susu pada sapi perah. Animal Agriculture Journal, 2(1), 168-174. https://ejournal3.undip.ac.id/index.php/aaj/article/view/2085

[47] Gad, N., Mohammed, A. M., \& Bekbayeva, L. K. (2013). Role of cobalt on cowpea growth and yield under different levels of nitrogen. World Applied Sciences Journal, 22(4), 470-478. https://doi.org/10.5829/idosi.wasj.2013.22.04.2982

[48] Purbalisa, W., \& Dewi, T. (2019). Remediasi tanah tercemar kobalt (Co) menggunakan bioremediator dan amelioran. Jurnal Tanah Dan Sumberdaya Lahan, 6(2), 1237-1242. https://doi.org/10.21776/ub.jts1.2019.006.2.4 